$\xi=-1$

\title{
Reflexive Self-Organizing Decision Support Systems for Development Governance
}

\author{
Lepskiy Vladimir ${ }^{1 *}$ \\ ${ }^{2}$ Institute of Philosophy Russian Academy of Sciences \\ *Corresponding authorE-mail: lepsky@tm-net.ru
}

\begin{abstract}
In the context of the development of ideas about scientific rationality (classical, non-classical, post-non-classical) the role and diversity of types of reflexive activity in supporting decision makers are justified. The basic types of reflexive activity and reflexive technologies in management are systematized. The trend of transition from control to self-regulation of reflexive activity in self-developing reflexively active environments is grounded.
\end{abstract}

Keywords: Reflexive Activity, Classical, Non-Classical, Post-Non-Classical Rationality, Subject- Oriented Approach, Activity Approach, Subject-Activity Approach, Self-Developing Reflexive-Active Environments.

\section{Introduction}

\subsection{The relevance of the study of the reflexive activity of} decision-makers

In recent years, the attention to reflexive activity in the works of leading specialists in system analysis and cybernetics has been increasing more and more $[1,2,3]$. To systemize the types of reflexive activity and reflexive technologies, it is advisable to consider them in the context of the development of scientific rationality [4].

The article substantiates the trend of increasing the role of reflexive activity in the processes of supporting decision-makers, reveals the specifics of reflexive activity in the context of the development of scientific rationality.

\subsection{Three types of scientific rationality}

In the historical evolution of science we can distinguish three types of scientific rationality: classical, non-classical and postnon-classical rationality [4].

The classical type of scientific rationality, concentrating attention on the object, in theoretical descriptions and explanations, tends to eliminate everything, which refers to the observer, the means and operations of a scientific activity.

The non-classical type of scientific rationality takes into account connections between the scientific knowledge of the object and the character of means and operations of activity.

The post-non-classical type of scientific rationality broadens the field of reflection over activity. It takes into account correlation of obtained knowledge of the object not only with the means and operations of activity, but also with value-goal structures. Here we explicate the connection between scientific goals and purposes and extra-scientific social values and goals.

It is important to note that the new type of scientific rationality is not alternative to the previous one; rather it includes previous types through the corresponding ontologies.

\subsection{Three types of scientific rationality}

In control three interrelated types of activity of subjects are represented: activity, communicative and reflexive $[5,6]$. To understand the specifics of their actualization in control and mechanisms of interaction, it is necessary to consider the philosophical and methodological foundations of ideas about control in the context of the development of scientific rationality. The basic philosophical and methodological grounds for analyzing the various types of activity of subjects in control are presented in the table 1.

Table 1: Basic philosophical and methodological bases

\begin{tabular}{|c|c|c|c|c|c|c|}
\hline \multicolumn{2}{|c|}{$\begin{array}{c}\text { Philosophical } \\
\text { level }\end{array}$} & \multicolumn{3}{|c|}{ Methodological level } & \multirow{2}{*}{$\begin{array}{c}\text { Theo- } \\
\text { retical } \\
\text { level } \\
\text { Basic } \\
\text { areas } \\
\text { of } \\
\text { knowl } \\
\text { edge }\end{array}$} & \multirow{2}{*}{$\begin{array}{l}\text { Types } \\
\text { of } \\
\text { re- } \\
\text { flex- } \\
\text { ive } \\
\text { activ- } \\
\text { ity }\end{array}$} \\
\hline $\begin{array}{l}\text { Type } \\
\text { of } \\
\text { sci- } \\
\text { en- } \\
\text { tific } \\
\text { ra- } \\
\text { tion- } \\
\text { ality }\end{array}$ & $\begin{array}{c}\text { Basic } \\
\text { philo- } \\
\text { sophi- } \\
\text { cal } \\
\text { ap- } \\
\text { proach } \\
\text { es }\end{array}$ & $\begin{array}{l}\text { Basic } \\
\text { para- } \\
\text { digms }\end{array}$ & $\begin{array}{c}\text { Basic } \\
\text { objects } \\
\text { of con- } \\
\text { trol. The } \\
\text { dominat- } \\
\text { ing } \\
\text { types of } \\
\text { activity }\end{array}$ & $\begin{array}{c}\text { Basic } \\
\text { scientific } \\
\text { ap- } \\
\text { proaches }\end{array}$ & & \\
\hline $\begin{array}{l}\text { Clas- } \\
\text { sical }\end{array}$ & $\begin{array}{l}\text { Posi- } \\
\text { tivism }\end{array}$ & $\begin{array}{l}\text { "Sub- } \\
\text { ject - } \\
\text { Ob- } \\
\text { ject" }\end{array}$ & $\begin{array}{c}\begin{array}{c}\text { Com- } \\
\text { plex }\end{array} \\
\text { system } \\
\text { Activity } \\
\text { in activi- } \\
\text { ty }\end{array}$ & $\begin{array}{l}\text { Activity } \\
\text { approach } \\
\text { Mono- } \\
\text { discipli- } \\
\text { nary } \\
\text { approach }\end{array}$ & $\begin{array}{c}\mathrm{Cy}- \\
\text { bernet } \\
\text { ics }\end{array}$ & $\begin{array}{c}\text { Per- } \\
\text { sonal } \\
\text { re- } \\
\text { flex- } \\
\text { ion }\end{array}$ \\
\hline $\begin{array}{l}\text { Non- } \\
\text { clas- } \\
\text { sical }\end{array}$ & $\begin{array}{l}\text { Philo- } \\
\text { sophi- } \\
\text { cal } \\
\text { con- } \\
\text { structi- } \\
\text { vism }\end{array}$ & $\begin{array}{l}\text { "Sub- } \\
\text { ject - } \\
\text { Sub- } \\
\text { ject" }\end{array}$ & $\begin{array}{c}\text { Active } \\
\text { systems } \\
\text { Com- } \\
\text { munica- } \\
\text { tive } \\
\text { activity }\end{array}$ & $\begin{array}{l}\text { Subject- } \\
\text { activity } \\
\text { approach } \\
\text { Interdis- } \\
\text { ciplinary } \\
\text { approach }\end{array}$ & $\begin{array}{l}\text { Sec- } \\
\text { ond- } \\
\text { order } \\
\text { cy- } \\
\text { bernet } \\
\text { ics }\end{array}$ & $\begin{array}{c}\text { Com } \\
\text { muni- } \\
\text { cative } \\
\text { re- } \\
\text { flex- } \\
\text { ion }\end{array}$ \\
\hline
\end{tabular}




\begin{tabular}{|c|c|c|c|c|c|c|}
\hline $\begin{array}{l}\text { Post- } \\
\text { non- } \\
\text { clas- } \\
\text { sical }\end{array}$ & $\begin{array}{c}\mathrm{Hu}- \\
\text { man- } \\
\text { istic } \\
\text { inter- } \\
\text { preta- } \\
\text { tion of } \\
\text { philo- } \\
\text { sophi- } \\
\text { cal } \\
\text { con- } \\
\text { structi- } \\
\text { vism }\end{array}$ & $\begin{array}{c}\text { "Sub- } \\
\text { ject - } \\
\text { Meta- } \\
\text { Sub- } \\
\text { ject" } \\
\text { "Self- } \\
\text { de- } \\
\text { velopi } \\
\text { ng } \\
\text { re- } \\
\text { flex- } \\
\text { ive- } \\
\text { active } \\
\text { envi- } \\
\text { ron- } \\
\text { ment" }\end{array}$ & $\begin{array}{l}\text { "Self- } \\
\text { develop- } \\
\text { ing } \\
\text { envi- } \\
\text { ron- } \\
\text { ments" } \\
\text { Reflex- } \\
\text { ive } \\
\text { activity }\end{array}$ & $\begin{array}{c}\text { Subject- } \\
\text { oriented } \\
\text { ap- } \\
\text { proach. } \\
\text { Trans- } \\
\text { discipli- } \\
\text { nary } \\
\text { approach }\end{array}$ & $\begin{array}{l}\text { Third- } \\
\text { order } \\
\text { cy- } \\
\text { bernet } \\
\text { ics [6] } \\
\text { (post- } \\
\text { non- } \\
\text { classi- } \\
\text { cal } \\
\text { cy- } \\
\text { bernet } \\
\text { ics of } \\
\text { self- } \\
\text { devel- } \\
\text { oping } \\
\text { reflex- } \\
\text { ive- } \\
\text { active } \\
\text { envi- } \\
\text { ron- } \\
\text { ments } \\
\text { ) }\end{array}$ & $\begin{array}{c}\text { Re- } \\
\text { flex- } \\
\text { ion of } \\
\text { stra- } \\
\text { tegic } \\
\text { sub- } \\
\text { jects }\end{array}$ \\
\hline
\end{tabular}

It is important to note that each type of scientific rationality, having its own specifics, is also a framework for incorporating the underlying type of scientific rationality into its toolkit. The postnon-classical type of scientific rationality is based on all the selected types of reflexive activity, including the basic types of reflexive activity for classics and non-classics. In post-non-classical scientific rationality, reflexive activity is dominant over activity and communicative activities.

\section{Results and Discussion}

\subsection{Reflective activity (classics)}

Classical scientific rationality, focusing attention on the object, seeks to reduce research to theoretical explanations and descriptions of everything that concerns the subject, means and activity operations.

In the context of classical scientific rationality, simplified ideas on the control of reflexive activity have been developed. Ignored the reflexive activity of the control object. At control of technical systems such approach quite justified itself. However, when controlling social systems (organizations, states, etc.), it turned out to be inadequate [1].

For the subject of control was both the desire to stimulate reflective activity, and to blocking the reflexive activity.

An example of ignoring the reflexive activity of decision makers is the theory of games and research of operations. A retreat before the problem of the complexity of the reflexive activity of the control objects, which were active subjects, led to the use of the criterion of guaranteed result, the search for the best of the worst results (maxmin). In the $1970 \mathrm{~s}$, there was a crisis in the use of game theory. There were difficulties in using this approach in the modelling of military operations, international relations and economic collisions.

The desire to stimulate the reflective activity of decision makers is associated with a "reflexive rise" beyond the stereotypes of decision making in problem situations. This problem was investigated in numerous works of psychologists and methodologists. It is associated with stimulating reflexive activity and increasing its complexity [1].

\subsection{Reflective activity (non-classics)}

Non-classical scientific rationality takes into consideration interactions between knowledge about object and character of activity means and operations. The results of scientific research are influenced by comprehending the correlation among the explained characteristics of objects and the features of means and scientific activity operations [4].

The decision maker becomes only one of the person in the specific system of the reflexive relations. This has created the basis for a transition from the paradigm of "subject - object" to the paradigm of "subject - subject". At the same time the role of reflexive activity has sharply increased [2]. Communicative reflexive activity [7] becomes the leading concern [3].

The idea of cybernetics of the second order offered by Von Foerster - "cybernetics of observing systems" - can be considered as a concept which corresponds best of all to non-classical scientific rationality.

The focus is on communicative reflection, which is understood as the ability to stand in the position of the researcher in relation to another "subject." The interdisciplinary idea of reflexion as the ability of some systems to build models of themselves and other systems, simultaneously seeing themselves building such models, has contributed to enriching the notion of control as naturalintellectual as well as artificial-intellectual systems.

The forms of communicative reflexive activity can be represented as a variety of reflexive technologies. The most famous is the technology of reflexive control, proposed by Lefebvre in the 1960s [7], as the process of transferring the grounds for decision making by one of the subjects to another. This technology has found wide application and development in various fields of scientific knowledge and applied works.

However, reflexive technologies can be considered more broadly if they include not only direct information effects on decisionmaking processes, but also indirect effects through the management of the structures of awareness processes-reflexive structures. We propose a classification of reflexive technologies in three basic groups: imitation of reflexive activity, reflexive control, reflexive programming. Table 2 presents examples of reflexive technologies and their graphic illustration.

The first group - "imitation reflexive activity" includes technologies of imitation of reflexive structures, processes and technologies, in particular, imitation of decision making processes, opening of reflexive control, opening of reflexive programming, etc. Reflexive activity of this group of technologies is associated with increasing the complexity of the subject of control.

The second group - "reflexive control" includes a variety of types of reflexive control. In these technologies, along with the increasing complexity of the subjects of control, control of the complexity of control objects is carried out.

The third group - "reflexive programming" includes various types of control of reflexive structures, processes and technologies.

The reflexive technology of the formation of "pulsating reflexion" forms the unstable state of the actual reflexive structure. This kind of technology was discovered by G. Bateson, which was investigated in the context of the concept of "double bind". Double bonds arise when one of the partners sends the other signals of opposite logic type [8].

Reflexive technology for the formation of "virtual reflexion" is associated with the active actions of the control object, on the basis of which the control object becomes a "virtual subject". The imitation of the reflexive activity of the "virtual subject" is extremely difficult.

The development of reflexive technologies had an impact on the development of the game approach and operations research [9]. 
Table 2: Graphic illustration of reflexive technologies imitation of reflective activity

\begin{tabular}{|c|c|}
\hline $\begin{array}{l}\text { REFLEXIVE } \\
\text { TECHNOLOGY }\end{array}$ & GRAPHICILLUSTRATION \\
\hline $\begin{array}{l}\text { Imitation of } \\
\text { reflexive } \\
\text { activity }\end{array}$ & $\mathrm{X} 4-\cdots-\mathrm{Y}$ \\
\hline $\begin{array}{l}\text { Simple reflexive } \\
\text { control }\end{array}$ & $\mathrm{X}$ \\
\hline $\begin{array}{l}\text { The opening of } \\
\text { reflexive control }\end{array}$ & $\mathrm{x}$ \\
\hline $\begin{array}{l}\text { Anticipating } \\
\text { Reflexive } \\
\text { Control }\end{array}$ & $x \frac{1}{4}$ \\
\hline $\begin{array}{l}\text { Double reflexive } \\
\text { control }\end{array}$ & $\neq Y$ \\
\hline $\begin{array}{l}\text { Reflexion } \\
\text { blocking }\end{array}$ & $\mathrm{X}=\mathrm{R}$ \\
\hline $\begin{array}{l}\text { Stimulation of } \\
\text { Reflexion }\end{array}$ & $\mathrm{X} \stackrel{\mathrm{R}^{\nabla}}{\longrightarrow} \mathrm{Y}$ \\
\hline $\begin{array}{l}\text { Reflexive } \\
\text { control lock }\end{array}$ & 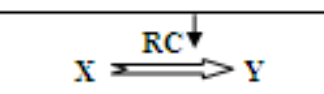 \\
\hline $\begin{array}{c}\text { The stimulation } \\
\text { of reflexive } \\
\text { control }\end{array}$ & $\mathrm{x} \stackrel{\mathrm{RCT}}{\longrightarrow} \mathrm{Y}$ \\
\hline $\begin{array}{l}\text { Formation of } \\
\text { new reflexive } \\
\text { positions }\end{array}$ & $\mathrm{x} \stackrel{\mathrm{RP}^{\dagger}}{\longrightarrow} \mathrm{Y}$ \\
\hline $\begin{array}{l}\text { Blocking of } \\
\text { available } \\
\text { specific } \\
\text { reflexive } \\
\text { positions }\end{array}$ & 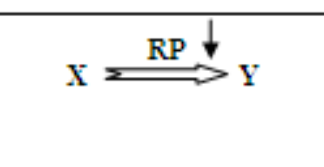 \\
\hline $\begin{array}{l}\text { Formation of } \\
\text { "pulaating } \\
\text { reflexion" }\end{array}$ & $\mathrm{x}=$ \\
\hline $\begin{array}{l}\text { Formation of } \\
\text { "virtual } \\
\text { reflexion" }\end{array}$ & $\mathrm{x}=\frac{\mathrm{B}}{2}$ \\
\hline
\end{tabular}

\subsection{Reflective activity (post-non-classics)}

Post-non-classical scientific rationality broadens the field of reflexion on scientific activity. It takes into consideration the correlation of the acquired knowledge about an object not only with the features of means and operations but also with valuable and target structures. At the same time the connection of inner scientific goals with social values and aims is explicated.

Self-developing systems are in the center of attention of post-nonclassical scientific rationality [4]. The paradigm "subject - selfdeveloping reflexive-active system (environment)" [10] becomes a key paradigm of control and cybernetics [6].

A self-developing reflexive-active environment is a metasubject, which possesses invariant similar to the properties of subjects: purposefulness (activity), reflexivity, communicativeness, sociality, ability to develop, etc. Such an environment has integrity that essentially distinguishes it from networks. This is an interaction of active elements, organized in a special way. Active elements can be created on the basis of natural intelligence (the personality, group, etc.), on the basis of artificial intelligence (agents) and also on the basis of integration of natural and artificial intelligence.

The organization of interaction of active elements among themselves and with the environment in general is defined by the system of values, principles, ontologies (maintenance, support, development, designing, providing innovations), criteria (efficiency, safety, development, satisfaction) and also by the specialized subject-focused information platform $[5,10,11]$.

Ontologies and principles of organization of self-developing reflexive active environments allow us to identify the basic mechanisms of self-regulation of reflective activity:

The mechanism of "reflexive rise" is the stimulation of reflective activity. When "points of interruption of various types of activity" arise. Methodological scheme "support".

The mechanism of "reflexive cooperation" is the stimulation of reflexive activity for long-term development. Methodological scheme of "development".

The mechanism of "active introduction of innovations" is the stimulation of reflexive activity when introducing innovations. Methodological scheme "implementation".

The mechanism of "curtailing established forms of activity", the transfer to active elements of the environment of established forms of activity of decision-makers. Decrease in the reflexive activity of subjects due to coagulation of established forms of activity in the environment. Methodological scheme "accompaniment".

The mechanism of "transfer of established forms of activity". Decrease in the reflexive activity of subjects due to the transfer to the environment of established forms of activity. Methodological scheme "accompaniment".

The mechanism of "openness to the development of new forms of activity," the stimulation or reduction of reflective activity due to the introduction or absorption of new forms of activity. Methodological scheme "Designing".

The mechanism of "active research of subjects" is the modeling of subjects in order to increase the capacity for selfregulation of reflective activity.

The mechanism of targeting a "specific subject", selfregulation of reflective activity, taking into account the models of specific subjects.

In all the mechanisms examined, the "double subject" principle is used $[1,6,10]$.

\section{Conclusion}

The increase in the role of ensuring the reflexive activity of decision-makers is justified. In the context of the development of scientific rationality, a variety of types of reflexive activity and technologies for their provision has been analyzed.

In the context of non-classical scientific rationality, the problem of accounting for reflective activity was included in the priority problems of support for decision makers.

In the context of post-non-classical scientific rationality, the problem of control reflexive activity is transformed into the problem of its self-regulation. The possibility of self-regulation is predetermined by ontologies and the principles of organizing a selfdeveloping reflexively active environment. This allows us to create new mechanisms for self-regulation of the reflective activity of decision-makers.

\section{Acknowledgement}

This work is partly funded by Russian Science Foundation, project 17-18-01326. 


\section{References}

[1] Lepskiy V. The Concept of Subject-oriented Computerization of Control Activity, Institute of Psychology RAS, Moscow, (1998). (in Russian).

[2] Umpleby Stuart A. "Second order science: logic, strategies, methods", Constructivist Foundations. Vol. 10 No. 1, (2014), pp. 16-23.

[3] Müller Karl H. "The Multiple Faces of Reflexive Research Designs" , Systemics, Cybernetics and Informatics, vol 13, No 6, (2015), pp.87-98.

[4] Stepin V. Theoretical Knowledge, Springer Verlag GMBH, (2005).

[5] Lepskiy V. Evolution of concepts about control (methodological and philosophical analysis, Kogito Center Publishing House, Moscow. 2015 (in Russian).

[6] Lepskiy V. Evolution of cybernetics: philosophical and methodological analysis, Kybernetes, Vol. 47., Issue: 2, (2018), pp.249-261, https://doi.org/10.1108/K-03-2017-0120

[7] Lefebvre V.A. The conflict structures, Vysshaya shkola, Moscow. 1967 (in Russian).

[8] Bateson G. Steps to an Ecology of Mind. N.Y.: Ballantine, 1972.

[9] Novikov D.A. Cybernetics: from Past to Future, Heidelberg: Springer, (2016)

[10] Lepskiy V. Reflexive and Active Environments of Innovative Development, Kogito-Center Publishing House, Moscow, (2010) (in Russian).

[11] Ilyin N, Malinetsky G, Kolin K, Zatsarinny A, Raikov A, Lepskiy V, Slavin B. Distributed situational centres system of cutting edge development. Management of Large-Scale System Development (MLSD), 2017 Tenth International Conference. 2-4 Oct. 2017. DOI:10.1109/MLSD.2017.8109638 